\title{
The Use of Priestly Legal Tradition in Joshua and the Composition of the Pentateuch and Joshua*
}

\author{
Pekka Pitkänen (University of Gloucestershire, UK)
}

\begin{abstract}
This article looks at how priestly legal materials can be seen to have been used in Joshua. This includes the allotment of towns of refuge, levitical towns, the concept of centralization of worship (Joshua 22:934) and the Passover. The argument will be that priestly material has been incorporated in a Deuteronomic framework and that Joshua can be seen as a document that quite uniquely combines Priestly and Deuteronomic legal materials. In this, Deuteronomic legal materials can be considered as encompassing priestly materials from an interpretative perspective, in line with the narrative order of Priestly and Deuteronomic materials in the Pentateuch. Relevant textual issues will also be taken into consideration, such as with the portrayal of the Passover in Joshua. In addition, the article considers issues that relate to theory construction and how they relate to the topic in question.
\end{abstract}

KEY WORDS: Literary Criticism; Priestly materials, Deuteronomic materials, Levitical towns; biblical legal texts.

\section{A INTRODUCTION}

Wellhausenian approaches to the study of the Pentateuch have typically postulated that priestly materials $(\mathrm{P}, \mathrm{H})$ are chronologically later than narrative and Deuteronomic materials. ${ }^{1}$ In terms of the study of the book of Joshua, the widespread acceptance of Noth's Deuteronomistic hypothesis ${ }^{2}$ fit very well with this reconstruction about the relative ordering of narrative, deuteronomistic and priestly materials. However, with recent developments in the scholarship of the Pentateuch and the historical books Joshua-Kings, the relative dating of the Pentateuchal sources has been questioned and the existence of a Deuteronomistic History has been disputed, if in fact there ever

* Article submitted: 3/03/2016; final peer reviewed: 6/07/2016; Article accepted: 6/07/2016. Pekka Pitkänen, "The Use of Priestly Legal Tradition in Joshua and the Composition of the Pentateuch and Joshua," Old Testament Essays 29/2 (2016): 318335, doi: http://dx.doi.org/10.17159/2312-3621/2016/v29n2a6

1 See Julius Wellhausen, Prolegomena zur Geschichte Israel, $6^{\text {th }}$ ed. (Berlin: Druck und Verlag Georg Reimer, 1905.

2 Martin Noth, The Deuteronomistic History, $2^{\text {nd }}$ ed. (Sheffield: Sheffield Academic Press, 1991. 
was a full consensus on these matters anyway. ${ }^{3}$ In addition, and in my view rightly so (especially considering how one can see the whole of Genesis-Joshua as a chiastic structure with promise-fulfilment themes), an increasing number of scholars have recently been moving towards a concept of a Hexateuch, even if this concept may be constituted differently from the time before Noth. ${ }^{4}$ And, methodologically, once a Hexateuchal approach is taken, or is even on the horizon, it is clear that an investigation of the book of Joshua is tied with, or at least related to, considerations that relate to the study of the Pentateuch also. A number of the newer Hexateuchal approaches still see priestly materials as a later layer in the work than materials that are Deuteronomic, even if the priestly materials may now be followed by post-priestly narrative layers. ${ }^{5}$ But there have also been scholars, such as Milgrom and Weinfeld, who have seen priestly materials as earlier than Deuteronomy, and it is notable that Milgrom explicitly favoured the concept of a Hexateuch. ${ }^{6}$ Interestingly, though, for Milgrom, and also Knohl, the Holiness School was the final redactor of the Pentateuch, in other words, while $\mathrm{P}$ was of earlier origin, $\mathrm{H}$ was something that was added on later. ${ }^{7}$ More broadly, an idea of $\mathrm{H}$ being later than $\mathrm{P}$ now seems to be most often followed. ${ }^{8}$

Again, we come back to the question of the composition of the Hexateuch. My intention is not to fully argue for a compositional hypothesis here as I have already done that elsewhere. ${ }^{9}$ I will therefore briefly summarise the model here and make further comments based on it and build on it for this article. I would like to note that the following presentation will be about

3 See most recently Benjamin Kilchör, Mosetora und Jahwetora: Das Verhältnis von Deuteronomium 12-26 zu Exodus, Levitikus und Numeri (Wiesbaden: Harrassowitz, 2015); Eckart Otto, Deuteronomium 1,1-4,43, vol. 1 of Deuteronomium 1-11, HThKAT (Stuttgart: Herders, 2012), 1-256.

4 See for example Jacob Milgrom, Numbers (Philadelphia and New York: Jewish Publication Society, 1989), xviii; cf. Otto, Deuteronomium 1,1-4,43; Eckart Otto, Deuteronomium 4,44-11,32, vol. 2 of Deuteronomium 1-11, HThKAT (Stuttgart: Herders, 2012).

5 See Reinhard Achenbach, Die Vollendung der Tora: Studien zur Redaktionsgeschichte des Numeribuches im Kontext von Hexateuch und Pentateuch (Wiesbaden: Harrassowitz Verlag: 2003); cf. Otto, Deuteronomium 1,1-4,43; Otto, Deuteronomium 4,44-11,32.

6 Milgrom, Numbers, xviii; Moshe Weinfeld, The Place of Law in the Religion of Ancient Israel (Leiden: E.J. Brill, 2004).

7 Israel Knohl, The Sanctuary of Silence: The Priestly Torah and the Holiness School (Minneapolis: Fortress Press, 1995).

8 See Christophe Nihan, From Priestly Torah to Pentateuch (Tübingen: Mohr Siebeck, 2007).

9 See Pekka Pitkänen, "Reading Genesis-Joshua as a Unified Document from an Early Date: A Settler Colonial Perspective," BTB 45 (2015): 3-31, doi: $10.1177 / 0146107914564822$. There have been no responses thus far to this proposal. 
plausibilities rather than certainties. In general, scholarly preferences can result in a variety of reconstructions, and, arguing for a particular position can sometimes resemble more of a religious argument than an academic one. In this, one may keep in mind that the route of most academics to Old Testament/Hebrew Bible studies is via theology and religious studies, and this may explain why some of the arguments in the field can be religiously charged, mutantis mutandis, or, more generally, have less to do with academic issues than claimed (cf. below). ${ }^{10}$

In relation to the enterprise, then, I believe it is easier (or at least as easy as with any other options) to conceptualise the option that priestly legal materials have been incorporated in the composition, especially in terms of the narrative. That is, whoever formed the narrative used priestly materials as components that were put in. I have already earlier argued that the Hexateuch was essentially composed by two authors working together, the first (A1) writing Genesis-Numbers and the second (AD) Deuteronomy and Joshua. ${ }^{11}$ Both used various sources as part of the work. The legal materials probably developed at least partially in parallel, even though the Deuteronomic legal materials were composed based on the Covenant Code and were aware of Priestly materials $(\mathrm{P}$ and $\mathrm{H})$ and at least partially supplemented them (e.g. the allowance of profane slaughter in Deut $12 \mathrm{vs}$ Lev 17). ${ }^{12}$ In this, I agree that $\mathrm{H}$ had built on $\mathrm{P}$ and was combined with it (cf. Figure 1 below). Incidentally, a recently published $\mathrm{PhD}$ dissertation in Germany has independently argued along similar lines, suggesting that Deuteronomy is subsequent to legal materials in Exodus-Numbers and builds on them. ${ }^{13}$ This makes sense from a narrative perspective. That is, it would be rather natural to see later materials in a narrative sequence as superseding earlier materials where the two might be in contradiction. And, based on for example what Kitchen and Lawrence have suggested, it is easy to see two covenants running through the Pentateuch, one in Exod 20-Lev 26 and another in Deut 5-28, with both starting with the Decalogue and ending in blessings and curses (materials in Exod 12-13 and Lev 27-Numbers could be seen as supplements in an ancient Near Eastern style). ${ }^{14}$

10 But, cf. also e.g. Clifford Geertz, Works and Lives: The Anthropologist as Author (Stanford: Stanford University Press, 1988), with implications for fields beyond anthropology as well.

11 Pitkänen, "Reading Genesis-Joshua," 4-10.

12 I will not attempt to elaborate a social context for the legal codes here. However, I do note that any contexts postulated by Wellhausenian approaches proceed from source critical reconstruction to reconstructing a social context, with very little external evidence involved.

13 Kilchör, Mosetora und Jahwetora, 1-326.

14 Kenneth A. Kitchen and Paul J. N. Lawrence, Treaty, Law and Covenant in the Ancient Near East, (Wiesbaden: Harrassowitz, 2012), 3: 127-131. 
We are then starting to arrive at a conceptualisation where Deuteronomy is aware of the priestly legal materials and is building on them. ${ }^{15}$ If this is the case, Joshua is likely to be proceeding similarly, especially if one follows a dual author hypothesis. However, there are also some differences. Whereas Deuteronomy does not reproduce priestly materials, Joshua does. Deuteronomy presents its own version of the laws based on priestly antecedents, and Joshua is then interestingly a document that explicitly combines both priestly and Deuteronomic legal perspectives. In terms of the narrative placement, Deuteronomy can be seen as partially an intrusion to the Hexateuchal narrative (see Figure 2), and yet it has been carefully integrated in it, being a farewell speech of Moses at the edge of the promised land. ${ }^{16}$ Joshua however completely mirrors materials from Genesis-Numbers and portrays how many issues anticipated there were fulfilled or otherwise put in effect in the so-called Promised Land. ${ }^{17}$ This is in particular the case with Josh 13-22 which mirror Num 27, 32, 34-36 closely. ${ }^{18}$ The Transjordanian issue in Num 32 is also notably mirrored in Joshua, with an inner "Deuteronomic" chiasm. 19 Importantly, as can be seen in Figure 3, while a number of themes can be traced back to Deuteronomy, there are equally a good number of points that have a direct correspondence only in Genesis-Numbers, including in terms of the utilisation of priestly legal materials. While one might wish to argue in terms of traditional redactional theories here, if one assumes that Joshua largely builds on what can be (presently) seen in Genesis-Numbers and Deuteronomy, one may at the very least equally argue that everything has been laid out in a rather

15 Again, for some very detailed argumentation in support of this premise, see Kilchör, Mosetora und Jahwetora, 1-326. Interestingly, and as far as I know, the argument in that dissertation is not in any way dependent on my work but comes to similar conclusions.

16 I have now argued that the narrative about Moses's death in Deut 32:48-52 and Deut 34:1-9 continue the story from Num 27:12-23 in a rather straightforward manner and were composed by A1 based on sources available to him and given to A2. Deut 31:14-23 is by AD (Deut 31:23 is clearly Deuteronomic; cf. e.g. Josh 1:6, which leaves only vv. 14-15 but which could have been composed based on knowledge of A1's work) or (in my view less likely) a later addition together with the Song of Moses in Deut 32:1-47; see Pekka Pitkänen, Numbers (unpublished manuscript [commentary], 2016), 170-171.

17 Interestingly, the distribution of the Levitical towns in Joshua is not exactly as specified in Num 35:6-8 (see Milgrom, Numbers, 290). The same goes with the allotments in Num 26:52-56 (see Pitkänen, Numbers, 167). It is easy to think that AD had a slightly differing view about the towns than A1, just as was for example the case with dealings with Edom in Num 20:14-21 vs. Deut 2 (see Pitkänen, Numbers, 143).

18 See Pitkänen, Numbers, 153, 171.

19 See Pekka Pitkänen, Central Sanctuary and Centralization of Worship in Ancient Israel: From the Settlement to the Building of Solomon's Temple, reissue with a new introduction by the author (Piscataway, N.J.: Gorgias Press, 2014), 191-211. 
straightforward manner. Such a model has the advantage of being a relatively simple one ${ }^{20}$ As part of this, specifically, one may note that it is not necessary to follow Deuteronomistic history based approaches that tend to forcibly, and in my view unconvincingly, minimise the role of priestly materials in the book of Joshua. ${ }^{21}$

I will next present some concrete examples in support of the proposed approach. I will concentrate only on examples of passages that may have parallels with priestly materials, even if I will mention parallels to Deuteronomy only. Figure 3 below may be consulted for the presentation. Some further details about source division and utilisation in certain individual cases are included in my commentary on Joshua. ${ }^{22}$

\section{B LINKS BACK TO PENTATEUCHAL LEGAL MATERIALS IN JOSHUA}

\section{The law of Moses}

The law of Moses in Josh 1:7-8; 8:31-34; 22:5; 23:6; and possibly 24:26 is largely a Deuteronomic concept. However, Exodus and Numbers may also be alluded to, at least by implication, also considering the reference in Num 31:21; cf. Lev 26:46. While there are some textual differences, including in Josh 1:7-8 (e.g. Law of Moses missing from Greek in v. 7), cumulatively, the law is referred to sufficiently to counter claims that, based on textual witnesses, the concept of a torah of Moses is a later addition. ${ }^{23}$ So these occurrences are in line with our premise.

\section{Children's questions}

Children's questions occur in Josh 4:6-7 and 22:24-28. The context can be Deuteronomic (Deut 6:7,20), but may also have a narrative-based (maybe traditionally E) background in Exod 12:26-27. In addition, Josh 4 and especially ch. 22:9-34 clearly include priestly features. Thus, the children's question may be linked with priestly features, even if the matter cannot be conclusively proved.

\section{Crossing of the Jordan}

The crossing of the Jordan in Josh 3-4 mirrors Exod 14-15 and includes priestly features. These include the mention of the ark and the priests as the carriers of it (cf. Josh 3:3 versus Num 4). Certainly one cannot say that the depictions in

20 Cf. the concept of Occam's razor, and cf. further below.

21 Cf. Noth, Deuteronomistic History, 121-135, 141-148.

22 Pekka Pitkänen, Joshua (Leicester: IVP, 2010), 110-401.

23 For textual issues, see Emanuel Tov, Textual Criticism of the Hebrew Bible, $3^{\text {rd }}$ ed. (Minneapolis: Fortress Press, 2012), 294-299 specifically on the book of Joshua. 
Pitkänen, "Priestly Legal Tradition in Joshua," OTE 29/2 (2016): 318-335 323

Joshua 3-4 involve direct quotation of priestly materials in the Pentateuch, however, the material in Joshua is at the minimum compatible with that in Numbers.

\section{Circumcision}

Circumcision in Josh 5:1-9 can be considered to refer to priestly materials in Genesis 17; Exod 12:44-48; Lev 12:3. Circumcision is not clearly referred to in Deuteronomy. This easily fits with the idea that the reference is to priestly legal materials.

\section{The Passover}

The Passover in Josh 5:10-12 could as such refer to any of the CC, Dt or P/H materials. The comment that unleavened bread was eaten the next day (v. 11), which is missing from Greek, is at the very least broadly in line with both Lev 23 and Exod 12 when one considers a day as both ending and starting from the evening and reads maharat in Josh 5:11 as apparently referring to the next morning, with the idea that the feast of unleavened bread "proper" starts on the day after the Passover. The relationship with Deuteronomy (16) seems unclear in this respect, but there is nothing in the passage that excludes the possibility of knowledge about, or even use of, priestly material, with or without the passage missing from Greek.

\section{Jericho}

The siege of Jericho (Joshua 6) refers to priestly materials, particularly the priests and the ark, even if the trumpets are not the silver trumpets of Num 10:1-10. ${ }^{24}$ Again, while a connection with Deuteronomy and other knowledge about trumpets is possible, a connection with priestly material is fairly natural, even if the description of the trumpets is not exactly like that in Num 10:1-10.

\section{The ban (herem)}

The ban (herem; Josh $7-8 ; 9 ; 10-12 ; 23: 3-5,7-10 ; 24: 8-13$ ) is primarily a Deuteronomic concept (e.g. Dt 7), and yet a total destruction, even if without the label herem, also in effect features in such passages as Num $31(\mathrm{P}$ or $\mathrm{H}$ narrative) and in Exod 17:8-15 (JE[E] in classical source criticism). And, one should note its occurrence in the Mesha stele outside the Bible. They are also in line with ancient Israelite settler colonialism that is manifest throughout Genesis-Joshua and as explicit commands in addition in Exod 23:20-33; 34:10-

${ }^{24}$ Cf. Pitkänen, Numbers, 98-100. 
324 Pitkänen, "Priestly Legal Tradition in Joshua," OTE 29/2 (2016): 318-335

16; Num 33:50-56. ${ }^{25}$ At the minimum, nothing is in contradiction with priestly materials here.

\section{Altar on Mount Ebal}

The altar on Mount Ebal (Josh 8:30-37) is clearly a Deuteronomic concept (Deut 27). I have elsewhere argued that Lev 17 has a paradigmatic concept of centralization on which Deuteronomy builds, and that Deuteronomy centralizes only under peaceful conditions when settlement has been completed (Deut 12:8-11). ${ }^{26}$ The book of Joshua assumes that this takes place in the latter days of Joshua (14:15; 21:43-45), after the events at Mount Ebal. So the situation can be considered to be in line with priestly legal materials.

\section{Hanging on a tree}

Hanging on a tree in Josh 10:26-27 can be considered to refer back to Deut 21:22-23. There are no legal parallels with priestly materials.

\section{Tribal allotments}

The tribal allotments in Joshua 13-19 clearly refer back to the book of Numbers 32 and $34{ }^{27}$ While the Transjordanian allotments do have a parallel in Deuteronomy (see Deut 3:12-22), the Cisjordanian allotments in effect do not, but can easily be considered to refer back to priestly materials in Num 34. In other words, clearly the allotments can be seen as a fulfilment of priestly injunctions in Numbers. One should also note that Num 32 and Josh 22:9-34 bracket the story about the Transjordanian allotments. ${ }^{28}$

\section{Caleb and Joshua's inheritance}

The fulfilment of Caleb and Joshua's inheritance in Josh 14:6-14; 15:10-19 and Josh 19:49-50 only has a counterpart in Deuteronomy in 1:36; 1:38. At the same time, this story can easily be seen as referring back to the priestly tradition in Numbers, at the minimum in Num 14:20-38; Num 26:65 and Num $32: 12$, which incorporate considerably more detail about the matter. Therefore, considering that there is a link to the priestly traditions seems very logical.

25 See Pekka Pitkänen, "Pentateuch-Joshua: A Settler-Colonial Document of a Supplanting Society", Settler Colonial Studies 4/3 (2014), 245-276, doi: 10.1080/2201473X.2013.842626; cf. Pitkänen, Numbers, 196-197.

26 See Pitkänen, Central Sanctuary and Centralization of Worship in Ancient Israel, 95-109.

27 Cf. Pitkänen, Numbers, 153.

28 See Pitkänen, Central Sanctuary, 210, largely based on David Jobling, "“The Jordan a Boundary': A Reading of Numbers 32 and Joshua 22," SBL Seminar Reports 19 (1980): 183-207, and cf. above, p. 4 in the Introduction. 
Pitkänen, "Priestly Legal Tradition in Joshua," OTE 29/2 (2016): 318-335 325

\section{Daughters of Zelophehad}

The daughters of Zelophehad (Josh 17:3-4) are only mentioned in the book of Numbers $(27 ; 36)$, in a priestly context $(\mathrm{P} / \mathrm{H}$ narrative/special legislation). Clearly the passage in Joshua can be read very naturally as being about the fulfilment of the Numbers passages.

\section{Tent of meeting}

The Tent of meeting (Josh $18: 1 ; 22: 19$ ) is clearly a priestly concept. It refers back to Exod 25-40 in particular. It is very unlikely that the tent in Exod 33:711 is referred to (whatever one makes of this apparent second tent). It is true that the "second" tent may feature in Deut 31:14, but the priestly concept clearly seems to be in mind in the book of Joshua, also considering that the setting up of the tent of meeting at Shiloh is considered as a restoration of creation in Genesis-Joshua. ${ }^{29}$

\section{Cities of refuge}

The cities of refuge in Josh 20 appear to refer back to both Deuteronomy and Numbers. The description conflates language from both Deuteronomy and Numbers. ${ }^{30}$ As Barmash would suggest it, "Joshua 20 is a Deuteronomic reworking of a priestly kernel." 31 Even if vv. 4-6 were not in the original, missing as they are from Greek, vv. 1-3 already support this idea.

\section{Levitical towns}

The Levitical towns in Joshua 21 are based on Num 35:1-8; Lev 25:32-34 and are a fulfilment of the Numbers passage, with Lev 25:32-34 already assuming the institution. The Levitical towns are not mentioned in Deuteronomy.

\section{The Eastern tribes}

The Eastern tribes feature in both Numbers and Deuteronomy. In Joshua 22, verses 1-8 can be explained on the basis of Deuteronomy alone, but vv. 9-34 clearly have a priestly character. I have elsewhere argued (and cf. my comments above in relation to the altar on Mount Ebal) that the priestly materials (Lev 17) prescribe centralization as only applicable in the wilderness and thus as paradigmatic for the land as a whole. ${ }^{32}$ Also, the centralization requirement in this passage is Deuteronomic and is valid now that Yahweh has

29 See Pitkänen, "Reading Genesis-Joshua," 13, for this concept and its implications for reading Genesis-Joshua as a document that legitimates ancient settler colonialism.

30 See Pitkänen, Joshua, 335-336.

31 Pamela Barmash, Homicide in the Biblical World (Cambridge: Cambridge University Press, 2005), 92.

32 See Pitkänen, Central Sanctuary, 75-94. 
given rest to the settling Israelites (Josh 14:15; 21:43-45 vs. Deut 12:8-11). ${ }^{33}$ Thus, one may argue that Joshua has used priestly materials for Deuteronomic purposes.

\section{Covenant renewal at Shechem}

It does not appear clear as to what legal materials Joshua 24 refers to. The book of the Law of God could be a separate document or could, in the understanding of the writer, be linked with Deuteronomy or, for example, even the Pentateuch (or even Genesis-Joshua) as a whole. The passage does not seem to offer either confirmation or refutation of the position taken here about the relationship of Deuteronomic and priestly materials.

\section{SUMMARY AND CONCLUSIONS}

It is easy to argue that the overall orientation and style of Joshua is Deuteronomic, ${ }^{34}$ and, as indicated above, I have elsewhere suggested that Deuteronomy and Joshua were composed together. I have then argued that for Joshua, the author has also incorporated priestly materials into his Deuteronomistic framework. Nothing in the book seems to be against such an idea. Adopting such a perspective makes the composition of the book neat and straightforward, enabling one to see essential unity and authorial purpose without complicated redactional considerations, even if this does not mean that such considerations should in themselves be rejected as a whole. Interestingly, such passages as Joshua 20 suggest conflation of priestly and Deuteronomic language. This hints towards tight integration of both priestly and Deuteronomic traditions in the book of Joshua, even when the overall framework has been determined by Deuteronomic concerns. Joshua seems to be unique in this respect, and, more generally, no other biblical book refers to Pentateuchal legal materials in such a close manner. Coming back to compositional considerations, if one sees Joshua as having been written together with Deuteronomy with more or less full knowledge of priestly materials, such a state of affairs is a very straightforward one to conceive. Interestingly, this position is in a number of respects in line with a Deuteronomistic History hypothesis. It is just that the "history" does not continue beyond Joshua, and that Joshua clearly has incorporated priestly materials. Naturally, and also considering ancient Near Eastern parallels, the assumption here is that the work may have gone through modifications as it was passed on through time. ${ }^{35}$

33 Cf. my comments above in relation to the altar on Mount Ebal.

34 See Gordon Wenham, "The Deuteronomic Theology of the Book of Joshua," JBL 90 (1971), 140-148.

35 See Pitkänen, Joshua, 247-264, and David M. Carr, The Formation of the Hebrew Bible: A New Reconstruction (New York: Oxford University Press, 2011). In the 
From the perspective of theory construction, such an approach may appear too "simple" to some. However, we have a very strong historical example about a case where a simpler theory has been agreed to have been the better one. Before the time of Copernicus, elaborate theories, involving what are called Ptolemaic epicycles, had been constructed around the theory that the earth was the centre of the Universe. It was the work of Copernicus and Kepler that explained things based on heliocentrism, and that made the complicated geocentric theories unnecessary. Interestingly, it took quite a while for the thoughts of Copernicus and Kepler to be generally accepted due to the European scholarly commitment spearheaded by the Catholic Church being strongly committed to a geocentric view. The geocentric view had of course been held for centuries, and therefore the weight of tradition was also behind it.

Overall, it generally seems that the biblical studies field, and within it especially the subfield of Pentateuchal studies, ultimately does not question its fundamental assumptions, even if a number of issues have without doubt been debated. $^{36}$ A nice contrast is the questioning that for example the overall archaeological discipline has undergone. ${ }^{37}$ This includes such issues as the criticism of the "requirement" of perusing "sacred academic texts" as a young scholar so as to qualify for acceptance in the field" ${ }^{38}$; attempts to legitimate the field of study by claiming that one must "imitate natural sciences"; 39 exclusivity of method; ${ }^{40}$ and a requisite that one must read extensively in an unfamiliar literature in order to understand a particular theory so as to be able to evaluate it, that is, claiming that non-followers of that particular theory are

course of time, Joshua came to be separated from Genesis-Deuteronomy in a "canonical" context; cf. Pitkänen, "Reading Genesis-Joshua", 19, and Otto, Deuteronomium 1,1-4,43, 231-257 for two views and related further comments on this.

${ }^{36}$ Such works as Roger N. Whybray, The Making of the Pentateuch: A methodological Study (Sheffield: JSOT Press, 1987) and Rolf Rendtorff, The Problem of the Process of Transmission in the Pentateuch (Sheffield: JSOT Press, 1990) do question many of the underlying assumptions of classical Pentateuchal criticism, as does the newly developed redactional layers approach referred to above, however, their basic premise is still fundamentally based on a development from simple to complex in the context of the history of ancient Israel.

37 See John Bintliff and Mark Pearce, eds., The Death of Archaeological Theory? (Oxford and Oakville: Oxbow books, 2011).

38 John Bintliff, "The Death of Archaeological Theory," in Bintliff and Pearce, eds., The Death of Archaeological Theory? (Oxford and Oakville: Oxbow books, 2011), 8.

39 Mark Pluciennik, "Theory, Fashion, Culture", in Bintliff and Pearce, eds., The Death of Archaeological Theory? (Oxford and Oakville: Oxbow books, 2011), 41.

40 Pluciennik, "Theory, Fashion, Culture," 40-41. 
ignorant and thus, by way of a familiar tactic in academic writing, claiming authority and putting the reader on the back foot. ${ }^{41}$

It is difficult to understand from an intellectual perspective why the assumption of development from simple to complex is still held in terms of the Israelite legal materials and societal development. An outdated anthropological model seems to be underlying this assumption, even if that is rarely articulated and accepted to be an anthropological theory. There is no comparable instance from any ancient Near Eastern, if even from any known society that attests a development of this type. In addition, the social scientific disciplines of anthropology and sociology that reveal patterns in the development of human societies had not yet developed, not to mention that nineteenth century scholars did not have access to the wealth of ancient Near Eastern data that attests great societal complexity in the second millennium BCE. Under such circumstances, I cannot but consider the tenacious adherence by some to the Wellhausenian scheme as anything but an outlook that is equivalent to religious fervor and has nothing to do with intellectual curiosity and a desire to genuinely reconstruct the past of an ancient society, or even the way that an ancient document may have been constructed. At the very least, an openness to a variety of possibilities should be entertained. ${ }^{42}$ As Bintliff notes in regard to archaeology, "Reliance on a personal dogma, an a priori claim that the "world works like this', surely impoverishes the researcher's ability to discover how the Past was created, since alternative approaches or insights are from the first ruled out of investigation," also, including biblical studies. Coming back to the comments made in regard to Joshua, I do not claim that the approach proposed must be the correct one to the exclusion of any other approach. But I see no reason why an approach, which in particular does not assume a Wellhausenian scheme (or perhaps dogma!) of development from simple to complex, should be excluded a priori, as some might wish to argue, especially when it provides a relatively simple and straightforward model to explain the relevant data. At the very least, I hope that an alternative approach can stimulate one to think about the interpretation of the Pentateuch and the book of Joshua. In some ways the approach outlined above can even be compared with postmodernism and radical orthodoxy in systematic theology. This approach questions the tenets of modernism and its achievements, namely Wellhausenian biblical criticism and its claim to "scientific objectivity" and a particular view of societal progress, returning to more traditional positions, that is, the essential unity of the Pentateuch and Joshua, and yet does not leave out of consideration what has come in between

41 Pluciennik, "Theory, Fashion, Culture," 40.

42 Overall, Bintliff and Pearce, eds., The Death of Archaeological Theory? argue for pluralism and eclecticism for archaeology, the topic of their study, and there is no reason to discount such argumentation as applying to biblical studies also.

43 Bintliff, "The Death of Archaeological Theory," 18. 
Pitkänen, "Priestly Legal Tradition in Joshua," OTE 29/2 (2016): 318-335 329

in scholarship. Nor is the position arrived at here a premodern one, in that for example, unity in the work is considered to be a product of utilisation of sources, the Pentateuch is seen together with Joshua and is not a work of a single author but in this case of two, and the work could have been modified and updated as it was passed through centuries in the Israelite society. The approach is also postcolonial in that Genesis-Joshua is seen as a legitimating document for ancient settler colonialism in the time of early Israel, also in contrast to a premodern approach that would assume a Mosaic authorship. ${ }^{44}$

\section{ADDENDUM}

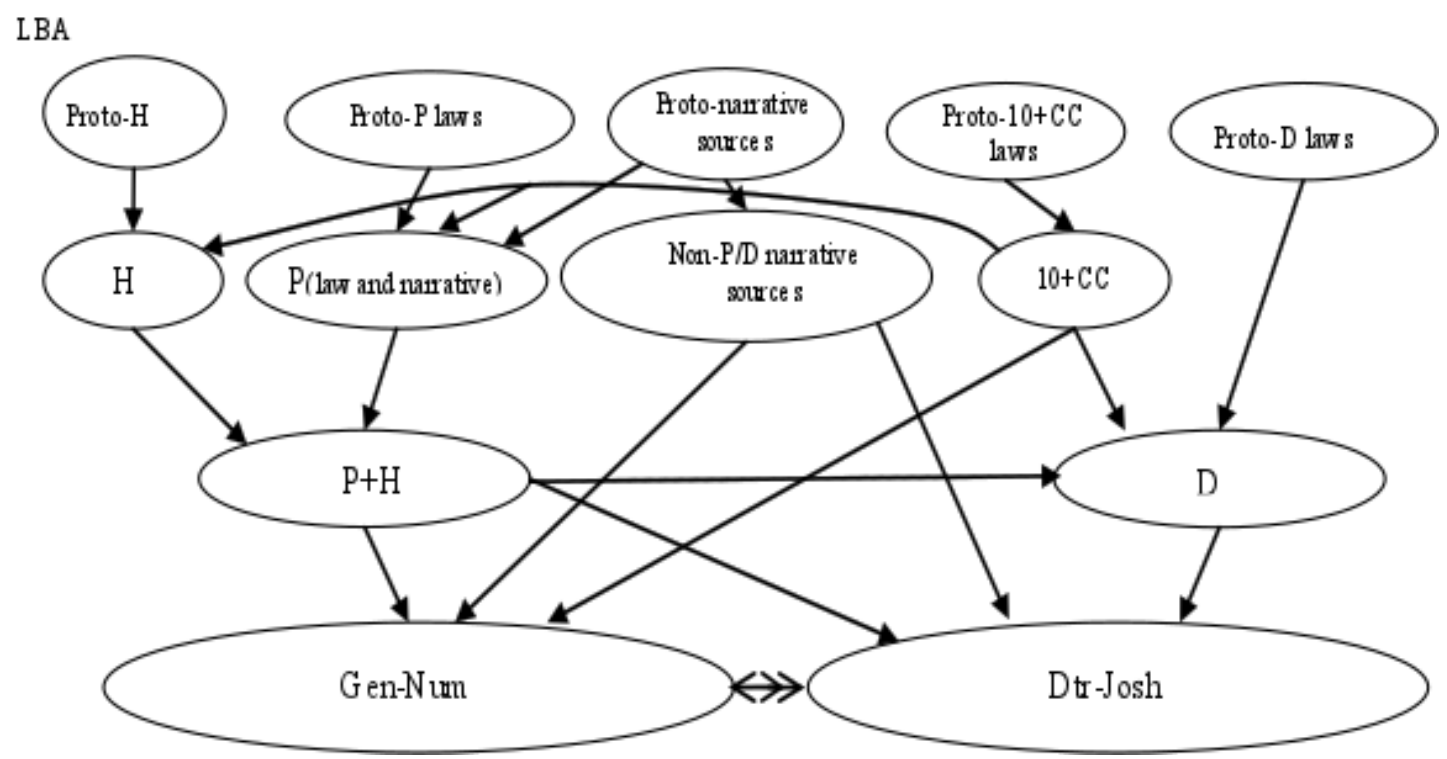

Figure 1: Composition of Genesis-Joshua (basic document) in its main outlines, based on Pitkänen, "Reading Genesis-Joshua as a Unified Document", 31, with slight modifications based on e.g. Kilchör, Mosetora und Jahwetora, 1-326.

44 See e.g. Pitkänen, "Pentateuch-Joshua: A Settler-Colonial Document of a Supplanting Society," and "Reading Genesis-Joshua as a Unified Document from an Early Date." 
A Genesis 1-11, Primeval History of the world as background for the history of Israel

B1 Genesis 12-50, The patriarchs Abraham, Isaac, Jacob and Joseph. The promise of the land of Canaan to the patriarchs (to Abraham first in Genesis 12), circumcision (Gen 17), Jacob removes foreign gods at Shechem (Gen 35), move to Egypt with Joseph (Gen 37ff), burial of Jacob in Canaan (Gen 49:29-50:14), death of Joseph in Egypt (Gen 50:22-26)

B2 Exodus 1-12, The exodus from Egypt. Moses's divine encounter for rescuing the Israelites (Ex 3), the plagues and leaving Egypt (Ex 7-12), Passover (Ex 12:1-30) and Circumcision (Ex 12:43-48)

B3 Exodus 13-15, Miraculous crossing of the Sea of Reeds into the wilderness

B4 Exodus 16-18, Wilderness before arriving at Mount Sinai. The miracles of manna and quails as provision for food (Ex 16) and water from the rock (Ex 17:1-7)

B5 Exodus 19-24, Covenant at Mount Sinai, initial covenant stipulations

B6 Exodus 25-31, Instructions for building the tabernacle (a tent sanctuary) as a place where Yahweh dwells

B7 Exodus 32, The idol of the golden calf and breaking of the covenant by the Israelites

B8 Exodus 33, Yahweh's presence reaffirmed

B7' Exodus 34, Renewal of the covenant, additional covenant stipulations

B6' Exodus 35-40, The building of the tabernacle (tent sanctuary) and its initiation

B5' Leviticus 1-Numbers 10:10, Further legal stipulations in relation to the covenant

B4' Numbers 10:11 - 36, Wilderness after leaving Mount Sinai, death of the first generation due to rebellion. The miracles of manna and quails (Num 11) and water from the rock (Num 20)

B4" Deuteronomy 1-34, Renewal of covenant for the second generation and further legal stipulations. Installation of Joshua as the new leader of the Israelites (Deut 31:1-8) and the death of Moses (Deut 34)

B3' Joshua 1-4, Preparations for the conquest (Josh 1-2) and miraculous crossing of the river Jordan into the land of Canaan (Josh 3-4)

B2' Joshua 5-12, Initial conquest/invasion (Josh 6-12) that begins with Jericho (Josh

6) and Ai (Josh 7-8). Circumcision (Josh 5:1-8), celebrating Passover (Josh 5:10-

11), ceasing of manna as food (Josh 5:12), Joshua's divine encounter for war (Josh 5:13-15)

B1' Joshua 13-24, Settlement of the land as fulfilment of the promise to the patriarchs.

Division of land (Josh 13-21), covenant renewed and foreign gods relinquished at Shechem (Josh 24) and the bones of Joseph buried in the promised land (Josh 24:32), Joshua dies and is buried (Josh 24:29-30). Restoration of creation by setting up the tabernacle at Shiloh, Josh 18:1 (A')

Figure 2. The chiastic structure of Genesis-Joshua, from P. Pitkänen, "Reading Genesis-Joshua as a Unified Document," 23, based on J. Milgrom, Numbers, in JPS Torah Commentary (Philadelphia and New York: Jewish Publication Society, 1989), xviii. 
Pitkänen, "Priestly Legal Tradition in Joshua," OTE 29/2 (2016): 318-335 331

\begin{tabular}{|c|c|c|c|c|c|c|}
\hline Description & Joshua & $\begin{array}{l}\text { Source } \\
\text { attribution }\end{array}$ & Gen-Num & Dtr & $\begin{array}{l}\text { Source } \\
\text { attribution } \\
\text { (from } \\
\text { Friedman as } \\
\text { one such } \\
\text { attribution, } \\
\text { also Knohl } \\
\text { as per P or } \\
\text { H) }\end{array}$ & Comments \\
\hline $\begin{array}{l}\text { Torah of } \\
\text { Moses }\end{array}$ & $\begin{array}{l}\text { Josh } \\
1: 7-8 ; \\
8: 31-34 ; \\
22: 5 ; \\
23: 6 ; \\
\text { possibly } \\
24: 26\end{array}$ & & $\begin{array}{l}\text { Num } \\
31: 21 ; \text { cf. } \\
\text { Lev 26:46 }\end{array}$ & $\begin{array}{l}\text { Dtr, } \\
\text { esp. } \\
4: 44 ; \\
17: 18- \\
20 ; \\
27: 3 \\
8,26 ; \\
28: 58 \\
61 ; \\
21: 21 \\
29 ; \\
30: 10 ; \\
31: 9 \\
11-13, \\
24 ; \\
32: 46 ; \\
33: 4 ;\end{array}$ & & $\begin{array}{l}\text { While the } \\
\text { primary } \\
\text { reference } \\
\text { seems to be } \\
\text { to Dtr, Ex- } \\
\text { Num may } \\
\text { also be } \\
\text { alluded to, at } \\
\text { least by } \\
\text { implication }\end{array}$ \\
\hline $\begin{array}{l}\text { Childrens' } \\
\text { questions }\end{array}$ & $\begin{array}{l}\text { Josh } \\
4: 6-7 \\
\end{array}$ & & & $\begin{array}{l}\text { Dtr } \\
6: 7,20\end{array}$ & & \\
\hline $\begin{array}{l}\text { Crossing of } \\
\text { the Jordan }\end{array}$ & Josh 3-4 & & $\begin{array}{l}\text { Ex 14-15; } \\
25: 10-22 ; \\
37: 1-9 ; \\
\text { Num 4:1- } \\
20 ; 10: 11- \\
36 \\
\text { (numbers } \\
\text { connection } \\
\text { implicit) }\end{array}$ & & $\begin{array}{l}\mathrm{JE}(\mathrm{J} \text { and } \mathrm{E}), \\
P\end{array}$ & $\begin{array}{l}\text { Crossing of } \\
\text { the Sea of } \\
\text { Reeds, the } \\
\text { ark and its } \\
\text { care by the } \\
\text { priests } \\
\text { (probably } \\
\text { Kohathites) }\end{array}$ \\
\hline Circumcision & $\begin{array}{l}\text { Josh } \\
5: 1-9\end{array}$ & & $\begin{array}{l}\text { Gen 17; Ex } \\
\text { 12:44-48; } \\
\text { Lev 12:3 }\end{array}$ & & $\begin{array}{l}\mathrm{P}^{*}(\mathrm{H} \text { in } \mathrm{vV} . \\
7-8) ; \mathrm{H} ; \mathrm{P}\end{array}$ & $\begin{array}{l}\text { Circumcision } \\
\text { is not clearly } \\
\text { referred to in } \\
\text { Dtr }\end{array}$ \\
\hline Passover & $\begin{array}{l}\text { Josh } \\
5: 10-12\end{array}$ & $\begin{array}{l}\text { Josh 5:10- } \\
12 \mathrm{D}+\mathrm{P}\end{array}$ & $\begin{array}{l}\text { Ex 12:1-28, } \\
\text { 43-49; } \\
\text { 13:3-10; } \\
\text { Ex 23:15; } \\
34: 25 ; \text { Lev } \\
\text { 23:4-8; } \\
\text { Num 9:1- } \\
\text { 14; Num } \\
28: 16-25\end{array}$ & $\begin{array}{l}\mathrm{Dt} \\
16: 1-8\end{array}$ & $\begin{array}{l}\mathrm{H} ; \mathrm{JE}(\mathrm{E}) ; \\
\mathrm{CC} ; \mathrm{CC} ; \mathrm{P} ; \\
\mathrm{H} ; \mathrm{P}^{*}(\mathrm{H} \text { in } \\
\text { vv. 22-23) }\end{array}$ & \\
\hline
\end{tabular}


332 Pitkänen, "Priestly Legal Tradition in Joshua," OTE 29/2 (2016): 318-335

\begin{tabular}{|c|c|c|c|c|c|c|}
\hline $\begin{array}{l}\text { Commander } \\
\text { of Yahweh's } \\
\text { army }\end{array}$ & $\begin{array}{l}\text { Josh } \\
5: 13-15\end{array}$ & & $\begin{array}{l}\text { Ex 3:1-6, } \\
7-22\end{array}$ & & $\mathrm{JE}(\mathrm{J}$ and $\mathrm{E})$ & \\
\hline Jericho & Josh 6 & & $\begin{array}{l}\text { Ex 25:10- } \\
22 ; 37: 1-9 ; \\
\text { Num } 10: 1- \\
10\end{array}$ & & & $\begin{array}{l}\text { Note the } \\
\text { priests and } \\
\text { the ark in } \\
\text { particular. }\end{array}$ \\
\hline $\begin{array}{l}\text { The ban } \\
\text { (herem) }\end{array}$ & $\begin{array}{l}\text { Josh 7- } \\
8 ; 9 ; 10- \\
12 ; \\
23: 3-5 \\
7-10 \\
24: 8-13\end{array}$ & & $\begin{array}{l}\text { Num } 31 \\
\text { (H, or P } \\
\text { narrative); } \\
\text { Ex 17:8-15 } \\
\text { (E) }\end{array}$ & $\begin{array}{l}\text { Dt } \\
6: 10- \\
11 ; 7 ; \\
13 ; 20 ; \\
\text { Ex } \\
23: 30- \\
33\end{array}$ & & \\
\hline $\begin{array}{l}\text { Joshua's } \\
\text { javelin }\end{array}$ & $\begin{array}{l}\text { Josh } \\
8: 18\end{array}$ & & Ex 17:11 & & $\mathrm{JE}(\mathrm{E})$ & $\begin{array}{l}\text { Moses's } \\
\text { hands and } \\
\text { Joshua's } \\
\text { javelin mirror } \\
\text { each other }\end{array}$ \\
\hline $\begin{array}{l}\text { Altar on } \\
\text { Mount Ebal }\end{array}$ & $\begin{array}{l}\text { Josh } \\
8: 30-35\end{array}$ & & & Dt 27 & & \\
\hline $\begin{array}{l}\text { Hanging on a } \\
\text { tree }\end{array}$ & $\begin{array}{l}\text { Josh } \\
10: 26- \\
27\end{array}$ & & & $\begin{array}{l}\mathrm{Dt} \\
21: 22- \\
23\end{array}$ & & \\
\hline $\begin{array}{l}\text { Killing of } \\
\text { Balaam }\end{array}$ & $\begin{array}{l}\text { Josh } \\
13: 22\end{array}$ & & Num 31:8 & & $\begin{array}{l}\mathrm{H}(\mathrm{P} \\
\text { narrative })\end{array}$ & \\
\hline $\begin{array}{l}\text { Tribal } \\
\text { allotments }\end{array}$ & $\begin{array}{l}\text { Josh 13- } \\
19\end{array}$ & & $\begin{array}{l}\text { Num 32; } \\
34 ;\end{array}$ & $\begin{array}{l}\text { (Dt 3; } \\
31: 7)\end{array}$ & $\begin{array}{l}\text { P (mixture; } \\
32 \text { possibly } \\
\text { also } \mathrm{H} \text { ) }\end{array}$ & $\begin{array}{l}\text { Note that Dtr } \\
\text { does not give } \\
\text { clear } \\
\text { (/explicit) } \\
\text { instructions } \\
\text { about land } \\
\text { division, but } \\
\text { Numbers } \\
\text { does }\end{array}$ \\
\hline $\begin{array}{l}\text { Caleb's } \\
\text { inheritance }\end{array}$ & $\begin{array}{l}\text { Josh } \\
14: 6-14 \\
15: 10- \\
19\end{array}$ & & $\begin{array}{l}\text { Num } \\
14: 20-38 ; \\
\text { Num } \\
26: 65 ; \\
\text { Num } 32: 12 \\
\end{array}$ & $\begin{array}{l}\mathrm{Dt} \\
1: 36\end{array}$ & $\begin{array}{l}\mathrm{JE}(\mathrm{J}) \text { and } \mathrm{P} ; \\
\mathrm{P} ; \mathrm{JE}(\mathrm{J})\end{array}$ & \\
\hline $\begin{array}{l}\text { Zelophehad's } \\
\text { daughters }\end{array}$ & $\begin{array}{l}\text { Josh } \\
17: 3-4\end{array}$ & & $\begin{array}{l}\text { Num 27; } \\
36\end{array}$ & & $\begin{array}{l}\mathrm{H}(\mathrm{P} \\
\text { narrative })\end{array}$ & Not in Dtr \\
\hline $\begin{array}{l}\text { Tent of } \\
\text { meeting }\end{array}$ & $\begin{array}{l}\text { Josh } \\
18: 1 ; \\
22: 19\end{array}$ & & $\begin{array}{l}\text { Ex 25-30; } \\
35-40 ; \text { Lev } \\
1-17\end{array}$ & Dt 12 & & \\
\hline $\begin{array}{l}\text { Joshua's } \\
\text { inheritance }\end{array}$ & $\begin{array}{l}\text { Josh } \\
19: 49- \\
50\end{array}$ & & $\begin{array}{l}\text { Num } \\
14: 20-38 ; \\
\text { Num } \\
\text { 26:65; } \\
\text { Num 32:12 } \\
\end{array}$ & & $\begin{array}{l}\mathrm{JE}(\mathrm{J}) \text { and } \mathrm{P} ; \\
\mathrm{P} ; \mathrm{JE}(\mathrm{J})\end{array}$ & \\
\hline Cities of & Josh 20 & $\mathrm{D}+\mathrm{P}$ & Num 35:9- & $\mathrm{Dt}$ & $\mathrm{H}(\mathrm{P}$ & Joshua \\
\hline
\end{tabular}


Pitkänen, "Priestly Legal Tradition in Joshua," OTE 29/2 (2016): 318-335 333

\begin{tabular}{|c|c|c|c|c|c|c|}
\hline Refuge & & & 34 & $\begin{array}{l}4: 41- \\
43 ; \\
19: 1- \\
13\end{array}$ & narrative) & $\begin{array}{l}\text { passage is a } \\
\text { fulfilment of } \\
\text { the Numbers } \\
\text { passage, in a } \\
\text { context where } \\
\text { land } \\
\text { conquered as } \\
\text { a whole, so } \\
\text { development } \\
\text { from D and } \\
\text { Numbers. Dt } \\
\text { law parallel } \\
\text { to the one in } \\
\text { Numbers, but } \\
\text { with only } \\
\text { three towns } \\
\text { set to tally } \\
\text { with Dtr's } \\
\text { setting in } \\
\text { Moab }\end{array}$ \\
\hline $\begin{array}{l}\text { Levitical } \\
\text { towns }\end{array}$ & Josh 21 & $\mathrm{P} / \mathrm{H}$ & $\begin{array}{l}\text { Num 35:1- } \\
8 ; \text { Lev } \\
25: 32-34\end{array}$ & & $\begin{array}{l}\mathrm{H} \text { (or } \mathrm{P} \text { if } \\
\text { narrative); } \mathrm{H}\end{array}$ & $\begin{array}{l}\text { Joshua } \\
\text { passage is a } \\
\text { fulfilment of } \\
\text { the Numbers } \\
\text { passage; Lev } \\
25: 33 \\
\text { assumes the } \\
\text { institution }\end{array}$ \\
\hline Eastern tribes & $\begin{array}{l}\text { Josh } \\
22: 1-8\end{array}$ & $\mathrm{D}$ & $\begin{array}{l}\text { Numbers } \\
32\end{array}$ & $\begin{array}{l}\text { Dt } \\
3: 12- \\
20\end{array}$ & $\begin{array}{l}\mathrm{H}(\mathrm{P} \\
\text { narrative })\end{array}$ & $\begin{array}{l}\text { Joshua } \\
\text { passage is the } \\
\text { fulfilment of } \\
\text { Numbers }\end{array}$ \\
\hline Eastern tribes & $\begin{array}{l}\text { Josh } \\
22: 9-34 ; \\
1: 12-15 ; \\
4: 12\end{array}$ & $\mathrm{P}$ & $\begin{array}{l}\text { Numbers } \\
32\end{array}$ & Dtr 12 & $\begin{array}{l}\mathrm{H}(\mathrm{P} \\
\text { narrative })\end{array}$ & $\begin{array}{l}\text { Joshua } \\
\text { passage } \\
\text { follows on } \\
\text { from vv. 1-8 } \\
\text { and refers } \\
\text { back to cult } \\
\text { centralization } \\
\text { that is a Dtr } \\
\text { concept that } \\
\text { builds also on } \\
\mathrm{P} / \mathrm{H} \text { view of } \\
\text { the matter }\end{array}$ \\
\hline $\begin{array}{l}\text { Childrens' } \\
\text { questions }\end{array}$ & $\begin{array}{l}\text { Josh } \\
22: 24- \\
28\end{array}$ & & & $\begin{array}{l}\text { Dtr } \\
6: 7,20\end{array}$ & & \\
\hline $\begin{array}{l}\text { Covenant } \\
\text { renewal at } \\
\text { Shechem }\end{array}$ & $\begin{array}{l}\text { Josh } \\
24: 1-28\end{array}$ & & $\begin{array}{l}\text { Gen 35; } \\
\text { Gen-Josh }\end{array}$ & & $\begin{array}{l}\mathrm{JE}(\mathrm{J} \text { and } \mathrm{E}) ; \\
P\end{array}$ & \\
\hline $\begin{array}{l}\text { Death and } \\
\text { burial notices }\end{array}$ & $\begin{array}{l}\text { Josh } \\
24: 29-\end{array}$ & & $\begin{array}{l}\text { Gen 50:22- } \\
26 ; \mathrm{Ex}\end{array}$ & & $\begin{array}{l}\mathrm{JE}(\mathrm{E}, \mathrm{J} \text { in } \mathrm{v} . \\
22 \mathrm{a}) ; \mathrm{JE}(\mathrm{E}) ;\end{array}$ & \\
\hline
\end{tabular}


334 Pitkänen, "Priestly Legal Tradition in Joshua," OTE 29/2 (2016): 318-335

\begin{tabular}{|l|l|l|l|l|l|l|}
\hline $\begin{array}{l}\text { of Joshua, } \\
\text { Joseph and } \\
\text { Eleazar }\end{array}$ & 33 & & $\begin{array}{l}13: 19 \\
\text { (Joseph); } \\
\text { Lev-Num } \\
\text { (Eleazar) }\end{array}$ & & P and H & \\
& & & & \\
\hline
\end{tabular}

Figure 3: Parallels between Joshua and Genesis-Numbers and Deuteronomy. Adapted from Pitkänen, "Reading Genesis-Joshua as a Unified Document," 24-27. Source divisions are heuristic.

\section{BIBLIOGRAPHY}

Achenbach, Reinhard, Die Vollendung der Tora: Studien zur Redaktionsgeschichte des Numeribuches im Kontext von Hexateuch und Pentateuch. Wiesbaden: Harrassowitz Verlag: 2003.

Barmash, Pamela. Homicide in the Biblical World. Cambridge: Cambridge University Press, 2005.

Bintliff, John and Mark Pearce, eds., The Death of Archaeological Theory? Oxford and Oakville: Oxbow books, 2011.

Bintliff, John. "The Death of Archaeological Theory." Pages 7-22 in The Death of Archaeological Theory? Edited by John Bintliff and Mark Pearce, Oxford and Oakville: Oxbow books, 2011.

Carr, David M. The Formation of the Hebrew Bible: A New Reconstruction. New York: Oxford University Press, 2011.

Geertz, Clifford. Works and Lives: The Anthropologist as Author. Stanford: Stanford University Press, 1988.

Jobling, David. "'The Jordan a Boundary': A Reading of Numbers 32 and Joshua 22." SBL Seminar Reports 19 (1980): 183-207.

Kilchör, Benjamin. Mosetora und Jahwetora: Das Verhältnis von Deuteronomium 12-26 zu Exodus, Levitikus und Numeri, BZABR 21. Wiesbaden: Harrassowitz, 2015.

Kitchen, Kenneth A., and Paul J. N. Lawrence. Vol. 3 of Treaty, Law and Covenant in the Ancient Near East. Wiesbaden: Harrassowitz, 2012.

Knohl, Israel. The Sanctuary of Silence: The Priestly Torah and the Holiness School. Minneapolis: Fortress Press, 1995.

Milgrom, Jacob. Numbers. JPS Torah Commentary. Philadelphia and New York: Jewish Publication Society, 1989.

Nihan, Christophe. Vol. 25 of From Priestly Torah to Pentateuch. FAT 2. Tübingen: Mohr Siebeck, 2007.

Noth, Martin. The Deuteronomistic History. $2^{\text {nd }}$ ed. JSOTSup 15. Sheffield: Sheffield Academic Press, 1991.

Otto, Eckart. Deuteronomium 1,1-4,43. Vol. 1 of Deuteronomium 1-11. HThKAT. Stuttgart: Herders, 2012. . Deuteronomium 4,44-11,32. Vol. 2 of Deuteronomium 1-11. HThKAT. Stuttgart: Herders, 2012.

Pitkänen, Pekka. Joshua, Apollos Old Testament Commentary. Leicester: IVP, 2010. . Central Sanctuary and Centralization of Worship in Ancient Israel: From the Settlement to the Building of Solomon's Temple, repr. of 2004 edn with a new introduction by the author. Piscataway, N.J.: Gorgias Press, 2014. 
Pitkänen, "Priestly Legal Tradition in Joshua," OTE 29/2 (2016): 318-335 335

. "Pentateuch-Joshua: A Settler-Colonial Document of a Supplanting Society." Settler Colonial Studies 4 (2014): 245-276. doi: 10.1080/2201473X.2013.842626

. "Reading Genesis-Joshua as a Unified Document from an early date: A Settler Colonial Perspective." Biblical Theology Bulletin 45 (2015): 3-31. doi: $\underline{10.1177 / 0146107914564822}$

. Numbers, unpublished manuscript (commentary), 2016.

Pluciennik, Mark. "Theory, Fashion, Culture." Pages 31-47 in The Death of Archaeological Theory? Edited by John Bintliff and Mark Pearce. Oxford and Oakville: Oxbow books, 2011.

Rendtorff, Rolf. The Problem of the Process of Transmission in the Pentateuch, JSOTSup 89. Sheffield: JSOT Press, 1990.

Tov, Emanuel. Textual Criticism of the Hebrew Bible. $3^{\text {rd }}$ ed. Minneapolis: Fortress Press, 2012.

Weinfeld, Moshe. The Place of Law in the Religion of Ancient Israel, VTSup 100. Leiden: E.J. Brill, 2004.

Wellhausen, Julius. Prolegomena zur Geschichte Israel. $6^{\text {th }}$ ed. Berlin: Druck und Verlag Georg Reimer, 1905.

Wenham, Gordon. "The Deuteronomic Theology of the Book of Joshua." Journal of Biblical Literature 90 (1971), 140-148.

Whybray, Roger N. The Making of the Pentateuch: A methodological Study, JSOTSup 53. Sheffield: JSOT Press, 1987.

Dr. Pekka Pitkänen is a Senior Lecturer at the University of Gloucestershire, FCH Campus, Swindon Road, Cheltenham GL50 4AZ, United Kingdom. Email:

ppitkanen@glos.ac.uk 